\title{
Parasites (Ellobiopsis chattoni Caullery, 1910) on Copepoda with two new host records, from Sea of Marmara, Turkey
}

\author{
M. Levent Artüz
}

\begin{abstract}
Background: In the various sites in Sea of Marmara, copepoda Acartia (Acartiura) clausi, Calanus euxinus, Centropages ponticus were invaded by Ellobiopsis chattoni.

Results: This study provides the first evidence of Centropages ponticus and Calanus euxinus being a host to Ellobiopsis chattoni and the first record of Ellobiopsis chattoni in the Sea of Marmara, Turkey.

Conclusions: Also this study emphasizes the consequences of parasitic infection in the case of the special position of Sea of Marmara.
\end{abstract}

Keywords: Copepoda, Ellobiopsis, Parasites, Sea of Marmara, Zooplankton

\section{Background}

The Sea of Marmara, with $933.3 \mathrm{~km}$ coastline, is an inland sea within Turkey with a maximum depth of $1272 \mathrm{~m}$. It has unique hydrodynamic features, due in large part to the structural characteristics of the Turkish straits (The Çanakkale Strait or Dardanelles, and the Boğaziçi or Bosphorus), which connect it to the Aegean and Black Seas, respectively. Collectively, the two Straits and the Sea of Marmara provide an important "acclimatization zone" for transiting species of pelagic fishes of Atlantic origin during their migration from the Black Sea to the Aegean and vice versa.

The Sea of Marmara has, in vertical section, three different water layers distinctly separated from each other. The top layer originates from low salinity Black sea water, in which salinity increases, but the thickness of the layer decreases considerably with the distance traveled from the Bosphorus to the Dardanelles by mixing and upwelling of the deeper layers originating from the Aegean and Mediterranean Seas.

The average depth of this top layer is about $25 \mathrm{~m}$, in which salinity ranges from 19 to $26 \%$ according to the season and inflow from the Black Sea. This mixing of

Correspondence: levent@artuz.com

Sevinç-Erdal İnönü Foundation, MAREM (Marmara Environmental Monitoring

Project) Naval Researches Department, 34810 Anadoluhisarı, Istanbul, Turkey the top and the middle water masses has also a considerable effect on the temperature of both layers.

The middle layer of water has its greatest thickness near the Dardanelles, where the top layer tends to diminish to a thin film of water of some few meters, but becomes markedly thinner from this point to the entrance of the Bosphorus. This high salinity water fills all the deeper parts of the Bosphorus below 25-30 m and extends, under certain conditions, into the depths of the Black Sea. There is also considerable changes in sea level caused by the outflow from the Black Sea, which is also largely responsible for the surface and deep currents in both directions, as well as the position of the vertical and horizontal boundaries of both layers.

The third and unaffected mass of water, which occupies all depths bellow $200 \mathrm{~m}$ in Sea of Marmara, has a constant temperature of $14.2{ }^{\circ} \mathrm{C}$ and salinity of $38.5 \%$ and no seasonal variations occurred (Artüz et al., 2007).

Copepoda often serves as hosts for parasitic protozoa, monogenea or even isopoda (Smyth 1994). Ellobiopsis spp. are regarded as dangerous parasites of copepoda. They can adversely affect fertility in females (Albaina \& Irigoien, 2006) and cause feminisation in males (Shields, 1994). There are also a number of studies reporting the lethal effects of Ellobiopsis spp. infection on copepoda (Timofeev, 2002). Ellobiopsis spp. are known to cause epizootics in its host populations, which may result 
in fundamental changes in ecological communities (Shields, 1994).

Representatives of the genus Ellobiopsis are common parasites of pelagic marine copepoda. Their taxonomic status remains vague, however, they have been classified as after Guiry (2015) as Infraphylum Protalveolata Cavalier-Smith, 1991; Order Ellobiopsida; Family Ellobiopsidae Coutière, 1911. The genus Ellobiopsis Caullery, 1910 consists of three species - Ellobiopsis chattoni Caullery, 1910; Ellobiopsis elongata Steuer, 1932 and Ellobiopsis fagei Hovasse, 1951.

Ellobiopsis spp. has been noted in many species of copepoda, including Acartia (Acartiura) clausi Giesbrecht, 1889. This study provides the first evidence of Calanus euxinus Hulsemann, 1991 and Centropages ponticus Karavaev, 1895 being a host to Ellobiopsis chattonii Caullery, 1910 and the first record of E. chattoni in the Sea of Marmara, Turkey.

\section{Results}

Ellobiopsis chattoni (Fig. 1a) were found in all research periods, and ranged from $4.6 \%$ (2007) to $8.6 \%$ (2012) total of all three copepoda species Acartia (Acartiura) clausi, Calanus euxinus, and Centropages ponticus; in two stations in 2007, in one station in 2008, in three station in 2009, in one station in 2010, in five stations in 2011 and in three stations in 2012 in the Sea of Marmara (Table 1).

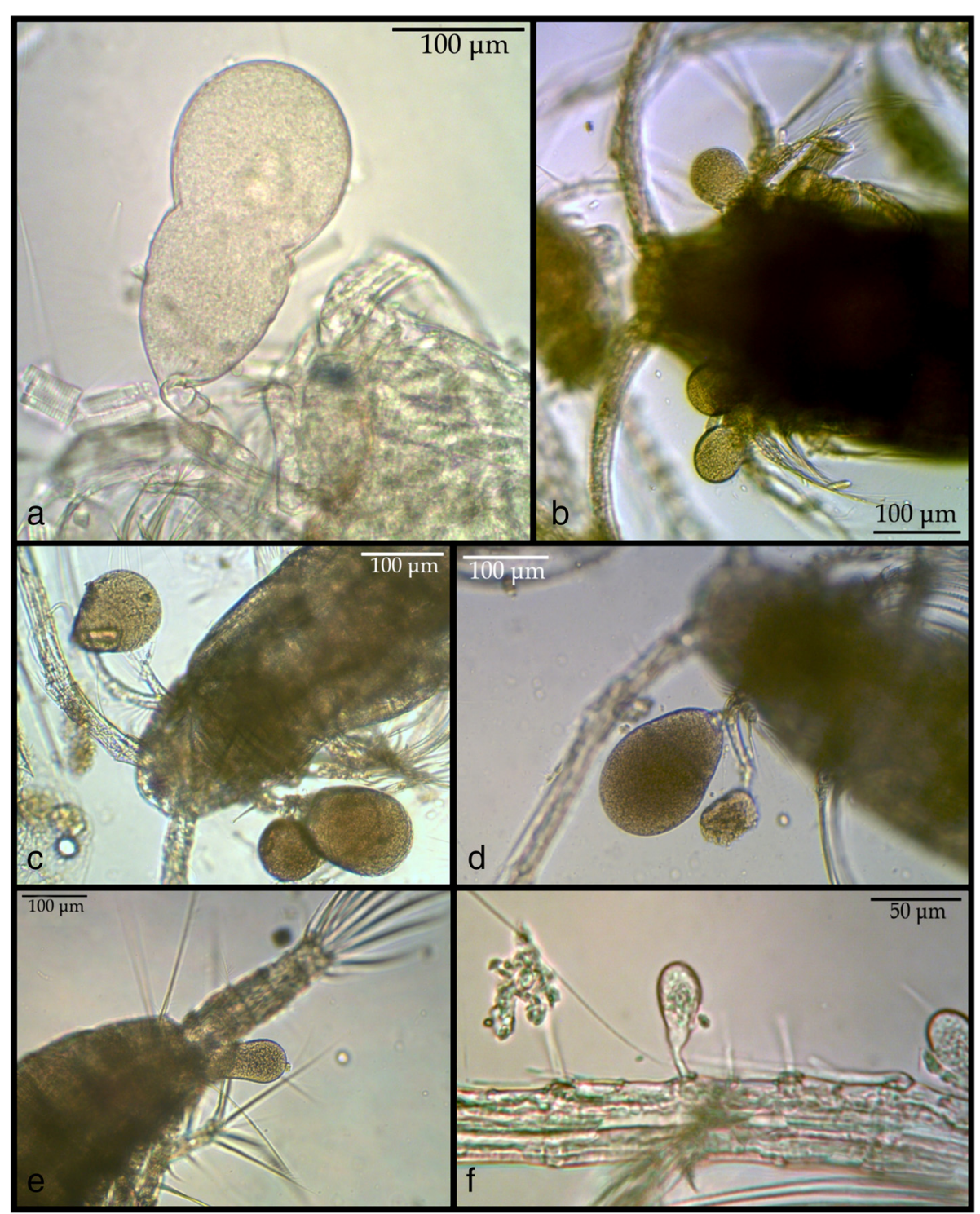

Fig. 1 (a) Ellobiopsis chattoni Caullery, 1910 (b) E. chattoni trophonts on C. ponticus dorsal view (c) E. chattoni trophonts on antenna and antennules of C. euxinus ventral view (d) Several E. chattoni trophonts on antennulla and maxilliped of C. euxinus ventral view (e) E. chattoni trophonts on 5. thoracic segment of A. clausi (f) E. chattoni trophonts on antenna of A. clausi 
The dominant taxa of copepoda of the Sea of Marmara were the most commonly attacked (Table 1) Acartia (Acartiura) clausi (37.8\% of all infested individuals), Calanus euxinus (19.5\% of all infested individuals) and Centropages ponticus (42.7 \% of all infested individuals).

Percentage of the infected to the uninfected individuals of the examined three copepoda species was in total 6.4 \% \pm 3.34 with by Acartia (Acartiura) clausi $7.3 \pm 3.32$, by Calanus euxinus $\mathbf{3 . 8} \pm 1.86$ and by Centropages ponticus $8.3 \pm 2.94$.

The mean values of counts, for $1 \mathrm{~cm}^{3}$ volume, of total examined species in annual basis were in 2007, 113; in 2008, 86; in 2009, 105; in 2010, 98; in 2011, 90; in 2012, 79 respectively.

The mean number of $E$. chattoni trophonts on each parasitized copepod individual was $3.64 \pm 1.99$, with a maximum of nine. The mean number of $E$. chattoni trophonts on each parasitized $A$. clausi individual was $3.97 \pm 2.19$, with a maximum of nine; on each parasitized C. euxinus individual was $3.66 \pm 1.98$ with a maximum of nine; and on each parasitized $C$. ponticus individual was $3.28 \pm 1.74$ with a maximum of eight (mean \pm st.dev.). The sampling period and station based percentage of infected individuals are given in Table 1.

The points of attachment of $E$. chattoni trophonts, in decreasing order of prevalence on copepoda were: antenna, mandible, antennules, maxilla, 5. thoracic segment, genital segment, rostrum, first pair of swimming legs, maxilliped (Fig. 1b-f).

Table 1 Date and station based distribution of the percentages of infected individuals to the non-infected individuals. Mean values of ten replicates of $1 \mathrm{~cm}^{3}$ from each station. ( $\% \pm s t$. dev.)

\begin{tabular}{llrrrr}
\hline Date & Station & \multicolumn{2}{l}{ Percentage (\%) } & Total (\%) \\
\cline { 3 - 6 } & $n r$ & \multicolumn{1}{l}{ A. clausi } & C. euxinus & C. ponticus & \\
\hline $09 / 08 / 2007$ & 36 & $\mathbf{5 . 6} \pm 1.63$ & $\mathbf{4} \pm 1.07$ & $\mathbf{5 . 6} \pm 2.87$ & $\mathbf{5 . 1} \pm 0.92$ \\
$07 / 08 / 2007$ & 40 & $\mathbf{4 . 5} \pm 2.08$ & $\mathbf{2 . 5} \pm 0.44$ & $\mathbf{5 . 3} \pm 1.70$ & $\mathbf{4 . 1} \pm 1.44$ \\
$11 / 08 / 2008$ & 40 & $\mathbf{7 . 2} \pm 1.39$ & $\mathbf{5 . 3} \pm 2.21$ & $\mathbf{7 . 5} \pm 1.77$ & $\mathbf{6 . 7} \pm 1.19$ \\
$05 / 08 / 2009$ & 17 & $\mathbf{1 0 . 9} \pm 1.42$ & $\mathbf{7 . 5} \pm 3.21$ & $\mathbf{1 0 . 2} \pm 1.65$ & $\mathbf{9 . 5} \pm 1.79$ \\
$06 / 08 / 2009$ & 24 & $\mathbf{7 . 9} \pm 1.29$ & $\mathbf{2 . 7} \pm 1.23$ & $\mathbf{9 . 9} \pm 3.46$ & $\mathbf{6 . 8} \pm 3.71$ \\
$11 / 08 / 2009$ & 40 & $\mathbf{4 . 5} \pm 0.74$ & $\mathbf{1 . 8} \pm 1.08$ & $\mathbf{5 . 5} \pm 1.70$ & $\mathbf{3 . 9} \pm 1.91$ \\
$11 / 08 / 2010$ & 17 & $\mathbf{1 0 . 7} \pm 3.94$ & $\mathbf{7 . 3} \pm 2.07$ & $\mathbf{1 0 . 8} \pm 2.01$ & $\mathbf{9 . 6} \pm 1.99$ \\
$06 / 08 / 2011$ & 30 & $\mathbf{2 . 1} \pm 0.82$ & $\mathbf{1 . 3} \pm 5.35$ & $\mathbf{2 . 5} \pm 1.15$ & $\mathbf{2 . 0} \pm 0.61$ \\
$07 / 08 / 2011$ & 40 & $\mathbf{5 . 1} \pm 2.75$ & $\mathbf{2 . 8} \pm 0.51$ & $\mathbf{8 . 2} \pm 1.93$ & $\mathbf{5 . 4} \pm 2.71$ \\
$07 / 08 / 2011$ & 40 & $\mathbf{5 . 6} \pm 0.63$ & $\mathbf{4 . 8} \pm 2.86$ & $\mathbf{1 0 . 4} \pm 4.37$ & $\mathbf{6 . 9} \pm 3.03$ \\
$07 / 08 / 2011$ & 34 & $\mathbf{5 . 8} \pm 1.82$ & $\mathbf{3 . 5} \pm 3.01$ & $\mathbf{5 . 2} \pm 3.44$ & $\mathbf{4 . 8} \pm 1.19$ \\
$08 / 08 / 2011$ & 35 & $\mathbf{5 . 9} \pm 1.80$ & $\mathbf{4 . 1} \pm 2.44$ & $\mathbf{8 . 1} \pm 3.22$ & $\mathbf{6 . 0} \pm 2.00$ \\
$22 / 07 / 2012$ & 19 & $\mathbf{1 4 . 3} \pm 2.59$ & $\mathbf{2 . 1} \pm 0.99$ & $\mathbf{1 1 . 8} \pm 1.77$ & $\mathbf{9 . 4} \pm 6.44$ \\
$26 / 07 / 2012$ & 3 & $\mathbf{1 2 . 1} \pm 3.96$ & $\mathbf{4 . 3} \pm 2.37$ & $\mathbf{1 2 . 9} \pm 2.98$ & $\mathbf{9 . 8} \pm 4.73$ \\
$28 / 07 / 2012$ & 26 & $\mathbf{7 . 5} \pm 3.54$ & $\mathbf{2 . 5} \pm 2.66$ & $\mathbf{1 0} \pm 2.49$ & $\mathbf{6 . 7} \pm 3.82$ \\
\hline
\end{tabular}

\section{Discussion}

During plankton surveys in Sea of Marmara, specimens of the copepoda Acartia (Acartiura) clausi, Calanus euxinus, Centropages ponticus infected with Ellobiopsis chattoni were collected. This finding seems important, both of the tree copepod species, indicated here, are important for the fishery of the area directly and via food web, especially C. ponticus is very important for the immigrant fishes such as Sarda sarda, (Zaitsev 1992).

The enormous effects would arise by the spread of any kind of the Sea of Marmara sourced negativity, especially given that it merges the Black Sea originated upper layer water mass with the Mediterranean Sea through the Aegean Sea and also the Mediterranean Sea originated limited scale of water mass with the Black Sea, as a conveyor.

Meanwhile, the Sea of Marmara has been subjected to various human impacts that have led to changes in the ecology of this inland sea. The main problem in the Sea of Marmara since 1980 is the growing pollution. All the settled areas around the Sea of Marmara are discharging the wastes using 'deep sea discharges' directly under the pycnocline-thermocline layer in the Sea of Marmara, without any treatment (Artüz et al., 2007).

In my opinion, the long-term changing of the chemical environmental variables such as $\mathrm{pH}$ changes (see Additional file 1), increasing pesticide concentration (Aksu \& Taşkın, 2012) and/or increasing amounts of chlorine in the Sea of Marmara, that originated in large quantities as a result of the cleaning fouling organisms on the inside of the direct discharge pipes of sewage and power plants, discharged directly to the water column, are effecting to the hosts immunity and making them more susceptible to the parasitic attack; but this hypothesis requires further study.

\section{Conclusions}

The occurrence of a possible attack of the parasite Ellobiopsis chattoni to some copepod species is significant because the subject has high social and economic importance. Besides the direct affect of growing pollution, the uniqueness of the Sea of Marmara from oceanographical and geological point of view plays an important role for the social and economic structure of the area.

In other words, parasitic attack to the copepod, position, pollution dilemma, and productivity of the Sea of Marmara should be considered as a block.

High probability of a fatal attack to the zooplankton communities will affect directly to the biodiversity via food web and finally to the fishery of the area. The effect may grow or/and spread exponentially to the adjacent seas, because of the oceanographical and biological specialities of the Sea of Marmara and its connections trough Turkish straits. It can be imagined the Sea of Marmara as a biological corridor between two totally 
Table 2 Date, Station Number, (BC) Beginning and (EC) Ending Coordinates of haul, Station Depth and (HM) Hauling Method ( $\mathrm{V}$; vertical, O; Oblique, $\mathrm{H}$; horizontal)

\begin{tabular}{|c|c|c|c|c|c|}
\hline Date & Station & $B C$ & EC & Depth $(\mathrm{m})$ & $\mathrm{HM}$ \\
\hline 09/08/2007 & 36 & $40^{\circ} 31.967^{\prime} \mathbf{N} / 026^{\circ} 59.983^{\prime} \mathrm{E}$ & $40^{\circ} 31.900^{\prime} \mathbf{N} / 026^{\circ} 59.850^{\prime} \mathrm{E}$ & 41 & $\mathrm{H}$ \\
\hline 07/08/2007 & 40 & $40^{\circ} 34.083^{\prime} \mathbf{N} / 027^{\circ} 14.850^{\prime} \mathbf{E}$ & $40^{\circ} 34.083^{\prime} \mathbf{N} / 027^{\circ} 14.850^{\prime} \mathbf{E}$ & 1050 & V \\
\hline $11 / 08 / 2008$ & 40 & $40^{\circ} 34.067^{\prime} \mathbf{N} / 027^{\circ} 14.817^{\prime} \mathrm{E}$ & $40^{\circ} 34.283^{\prime} \mathbf{N} / 027^{\circ} 14.767^{\prime} \mathbf{E}$ & 1000 & $\mathrm{O}$ \\
\hline 05/08/2009 & 17 & $40^{\circ} 40.617^{\prime} \mathbf{N} / 028^{\circ} 33.933^{\prime} \mathrm{E}$ & $40^{\circ} 40.450^{\prime} \mathrm{N} / 028^{\circ} 34.500^{\prime} \mathrm{E}$ & 427 & $\mathrm{O}$ \\
\hline 06/08/2009 & 24 & $40^{\circ} 31.883^{\prime} \mathrm{N} / 027^{\circ} 59.917^{\prime} \mathrm{E}$ & $40^{\circ} 31.883^{\prime} \mathbf{N} / 027^{\circ} 59.917^{\prime} \mathrm{E}$ & 45 & V \\
\hline $11 / 08 / 2009$ & 40 & $40^{\circ} 48.233^{\prime} \mathbf{N} / 027^{\circ} 27.550^{\prime} \mathrm{E}$ & $40^{\circ} 48.167^{\prime} \mathbf{N} / 027^{\circ} 27.433^{\prime} \mathbf{E}$ & 1100 & $\mathrm{O}$ \\
\hline $11 / 08 / 2010$ & 17 & $40^{\circ} 40.417^{\prime} \mathbf{N} / 028^{\circ} 33.100^{\prime} \mathbf{E}$ & $40^{\circ} 40.167^{\prime} \mathbf{N} / 028^{\circ} 32.283^{\prime} \mathbf{E}$ & 455 & $\mathrm{O}$ \\
\hline 06/08/2011 & 30 & $40^{\circ} 21.900^{\prime} \mathbf{N} / 027^{\circ} 42.983^{\prime} \mathbf{E}$ & $40^{\circ} 21.833^{\prime} \mathbf{N} / 027^{\circ} 43.017^{\prime} \mathbf{E}$ & 38 & $\mathrm{H}$ \\
\hline 07/08/2011 & 40 & $40^{\circ} 48.167^{\prime} \mathrm{N} / 027^{\circ} 26.500^{\prime} \mathrm{E}$ & $40^{\circ} 48.200^{\prime} \mathbf{N} / 027^{\circ} 25.500^{\prime} \mathrm{E}$ & 800 & $\mathrm{O}$ \\
\hline 07/08/2011 & 40 & $40^{\circ} 48.183^{\prime} \mathbf{N} / 027^{\circ} 27.600^{\prime} \mathrm{E}$ & $40^{\circ} 47.733^{\prime} \mathbf{N} / 027^{\circ} 26.667^{\prime} \mathbf{E}$ & 1000 & O \\
\hline 07/08/2011 & 34 & $40^{\circ} 54.233^{\prime} \mathbf{N} / 027^{\circ} 33.633^{\prime} \mathrm{E}$ & $40^{\circ} 54.233^{\prime} \mathbf{N} / 027^{\circ} 33.633^{\prime} \mathbf{E}$ & 187 & V \\
\hline 08/08/2011 & 35 & $40^{\circ} 28.750^{\prime} \mathbf{N} / 026^{\circ} 59.533^{\prime} \mathrm{E}$ & $40^{\circ} 28.683^{\prime} \mathbf{N} / 026^{\circ} 59.483^{\prime} \mathrm{E}$ & 55 & $\mathrm{H}$ \\
\hline $22 / 07 / 2012$ & 19 & $40^{\circ} 56.600^{\prime} \mathbf{N} / 028^{\circ} 33.583^{\prime} \mathrm{E}$ & $40^{\circ} 56.600^{\prime} \mathbf{N} / 028^{\circ} 33.583^{\prime} \mathrm{E}$ & 59 & V \\
\hline 26/07/2012 & 3 & $40^{\circ} 42.400^{\prime} \mathbf{N} / 029^{\circ} 04.350^{\prime} \mathrm{E}$ & $40^{\circ} 42.450^{\prime} \mathbf{N} / 029^{\circ} 04.967^{\prime} \mathbf{E}$ & 1200 & $\mathrm{O}$ \\
\hline 28/07/2012 & 26 & $40^{\circ} 25.083^{\prime} \mathbf{N} / 028^{\circ} 02.967^{\prime} \mathbf{E}$ & $40^{\circ} 25.083^{\prime} \mathbf{N} / 028^{\circ} 02.967^{\prime} \mathbf{E}$ & 44 & V \\
\hline
\end{tabular}

different basins with different characteristics such as the Black Sea and the Mediterranean Sea.

\section{Methods}

\section{Collection of material}

Plankton samples were collected between years 2007 and 2012 by annual surveys as part of the MAREM (Marmara Environmental Monitoring) project. The details of hauls are given in Table 2 and the station locations are given in Fig. 2.

Plankton net with a $650 \mathrm{~mm}$ net diameter and of $0.180 \mathrm{~mm}$ mesh size were used as sampling gear. Two replicates were taken at each station. For the vertical haul, the net lowered to the maximum depth and hauled all the water column, for oblique hauls used closed nets with same sizes from the depth of thermocline layer

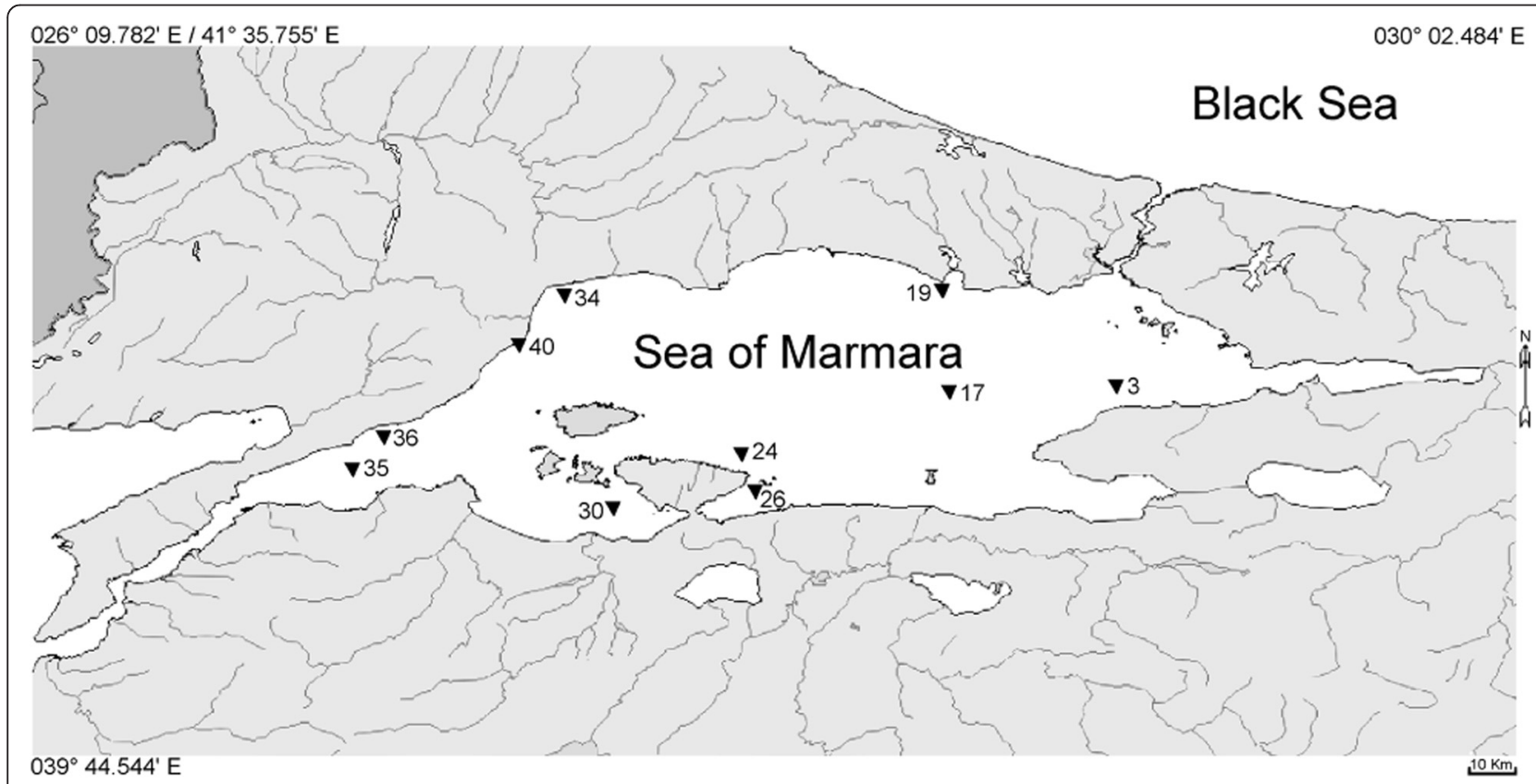

Fig. 2 Map of the Sea of Marmara and the location of the sampling stations 
(average $25 \mathrm{~m}$ depth) and horizontal hauls were realized of $0.5 \mathrm{~m}$ depth, with $5 \mathrm{~min}$ duration.

Samples were preserved immediately after collection, in a $4 \%$ solution of borax-buffered formaldehyde in seawater. After fixation, samples were precipitated by waiting; liquid level minimized material were rinsed and random sample replicas of ten pieces of each $1 \mathrm{~cm}^{3}$ were picked up from each sample group. Infected and non-infected individuals for each $1 \mathrm{~cm}^{3}$ replica were counted and the average percentages were calculated. Additionally 500 infected individuals of A. clausi; 500 infected individuals of C. euxinus; 500 infected individuals of $C$. ponticus were examined for the number of attached trophonts and for infesting point of Ellobiopsis chattoni. All samples are bar-coded and listed in MAREM database.

\section{Species identification}

Principal literature used for the identification of Ellobiopsis chattoni was from Caullery (1910) and Hovasse (1952). The biological characteristics of the copepoda were compared with the original descriptions. Subsequent, detailed descriptions of these species published by Boxshall \& Halsey (2004) were also used for comparison.

\section{Photographic documentation}

Photographs of copepoda and parasites were captured using a DCM 500 digital camera mounted on an Olympus trinocular microscope, and prepared with HeliconFocus software.

\section{Availability of supporting data}

The data sets supporting the results of this article are available in the MAREM (Marmara Environmental Monitoring) database repository, http://prog.marem.org

\section{Additional file}

Additional file 1: Average long-term $\mathrm{pH}$ distribution/fluctuation of whole Sea of Marmara area incl. Turkish straits, during summer seasons, in depth basis between years 2005 and 2014. pH data sheet's between 2005 and 2014. (PDF $535 \mathrm{~kb})$

\section{Acknowledgements}

I acknowledge the Sevinç-Erdal İnönü Foundation that oversaw the long-term Marmara Environmental Monitoring project. I also acknowledge the crew of the vessel 'Oktay 4' for their help in collecting the material. I also would like to thank Geoff Boxshall for his kind help during the copepoda identification.

Received: 2 February 2016 Accepted: 8 February 2016

Published online: 08 March 2016

\section{References}

Aksu A, Taşkın ÖS. Organochlorine residue and toxic metal ( $\mathrm{Pb}, \mathrm{Cd}$ and $\mathrm{Cr}$ ) levels in the surface sediments of the Marmara Sea and the coast of Istanbul, Turkey. Mar Pollut Bull. 2012;64(5):1060-2.

Albaina A, Irigoien X. Fecundity limitation of Calanus helgolandicus, by the parasite Ellobiopsis sp. J Plankton Res. 2006;28(4):413-8.
Artüz ML, Okay IA, Mater B, Artüz OB, Gürseler G, Okay N. Bilimsel Açıdan Marmara Denizi. Istanbul: Union of Turkish Bar Associations publication; 2007 (in Turkish).

Boxshall GA, Halsey SH. An introduction to copepod diversity. Ray Society; 2004

Caullery M. Ellobiopsis chattoni n.g., n.sp. parasite de Calanus helgolandicus Claus, appartenant probablement aux P'eridiniens. Bulletin Scientifique de la France et de la Belgique. 1910;44:201-14.

Guiry MD. Ellobiopsis Caullery, 1910. In: Guiry MD. \& Guiry GM. 2015. AlgaeBase World-wide electronic publication, National University of Ireland, Galway (taxonomic information republished from AlgaeBase with permission of MD. Guiry). 2015. http://www.marinespecies.org/aphia.php?p=taxdetails\&id=562628. Accessed 2015 April 07.

Hovasse R. Ellobiopsis fagei Hovasse, Ellobiopsidé parasite, en Méditerranée, de Clausocalanus arcuicornis Dana. Bull Inst Oceanogr. 1952;1016:1-12.

Shields JD. The parasitic dinoflagellates of marine crustaceans. Annu Rev Fish Dis. 1994:4:241-71.

Smyth JD. Introduction to animal parasitology. Cambridge University Press; 1994.

Timofeev SF. The effect of the parasitic dinoflagellate Ellobiopsis chattoni (Protozoa: Mastigophora) on the winter mortality of the calanoid copepod Calanus finmarchicus (Crustacea: Copepoda) in the Norwegian Sea. Parazitologiya. 2002;36(2):158-62 (in Russian).

Zaitsev YP. Recent changes in the trophic structure of the Black Sea. Fish Oceanogr. 1992;1(2):180-9.

Submit your next manuscript to BioMed Central and we will help you at every step:

- We accept pre-submission inquiries

- Our selector tool helps you to find the most relevant journal

- We provide round the clock customer support

- Convenient online submission

- Thorough peer review

- Inclusion in PubMed and all major indexing services

- Maximum visibility for your research 